\title{
Effect of an unusual source of methionine on the performance of organic chickens
}

\author{
Luiz Carlos Demattê Filho • Dayana Cristina de Oliveira Pereira • \\ Gustavo do Valle do Pereira • Christian Güdde Beutner
}

Received: 19 November 2014 / Accepted: 16 June 2015 /Published online: 30 June 2015

(C) Springer Science+Business Media Dordrecht 2015

\begin{abstract}
The use of amino acids from alternative sources to reduce costs and increase or maintain poultry production levels is crucial to succeed in competitive industry. This study investigated the alternative methionine effects obtained from soybean compared to synthetic DL-methionine - $99 \%$ on the broilers performance in the production periods of 1-21 and 1-42 days of age. A total of 720 pullets were included in a completely randomized design with four treatments and six replicates of 30 birds. They received water and food ad libitum throughout the production phase. Diets consisted of $\mathrm{T} 1$-reference diet formulated with synthetic methionine (DL-methionine-99\%); T2 - diet replacing $100 \%$ of synthetic methionine with alternative methionine; T3 - diet replacing $110 \%$ of synthetic methionine with alternative methionine, and T4 - diet
\end{abstract}

L. C. Demattê Filho • D. C. d. O. Pereira $(\bowtie) \cdot$

G. d. V. d. Pereira

CPMO, Ipeúna, SP, Brazil

e-mail: dayana.pereira@cpmo.org.br

L. C. Demattê Filho

e-mail: luiz.dematte@cpmo.org.br

G. d. V. d. Pereira

e-mail: gustavo.valle@cpmo.org.br

L. C. Demattê Filho

ESALQ/CENA, Piracicaba, SP, Brazil

D. C. d. O. Pereira

ESALQ-USP, Piracicaba, SP, Brazil

C. G. Beutner

FCAVJ-UNESP, Jaboticabal, SP, Brazil

e-mail: cbeutner@gmail.com replacing $120 \%$ of synthetic methionine with alternative methionine. At 1-21 days of age, there was a significant difference $(p<0.05)$ among treatments in daily gain weight (DWG), live weight (LW), and feed intake (FI). However, no differences were observed $(p>0.05)$ in feed conversion (FC) and mortality rates. At 42 days of age, a significant difference $(p<0.05)$ in DWG, LW, and FC parameters was observed among treatments, but there were no differences in FI and mortality. Broilers supplemented with alternative methionine showed significantly lower DWG, LW, FI, productive efficiency index (PEI), and flock uniformity (FU) and showed higher FC compared to animals supplemented with synthetic methionine. The synthetic methionine replacement resulted in lower broiler performance. More researches are necessary to promote better alternative diets for this system.

Keywords Alternative feed source - Broiler chickens · Methionine · Organic system

\section{Introduction}

The Brazilian poultry industry has excelled in the world market in recent years by its increasing quality and production, arising from the constant use of new technologies in the areas of nutrition, genetic improvement, disease control, and sanitary management (Belusso and Hespanhol 2010). Consequently, indicators of Brazilian poultry production have surpassed those reported in other countries (Espíndola 2009). 
Table 1 Effect of treatments on daily weight gain (DWG), live weight (LW), feed intake (FI), feed conversion (FC), and mortality (MO) in broilers of 1-21 days old

\begin{tabular}{|c|c|c|c|c|c|}
\hline Treatments & DWG (g) & LW (g) & $\mathrm{FI}(\mathrm{g})$ & $\mathrm{FC}$ & $\mathrm{MO}(\%)$ \\
\hline T1-99\% DL-methionine & $38.17^{*}$ & $843.79 *$ & $1287.17^{*}$ & $1.59 *$ & $1.11^{*}$ \\
\hline T2 - alternative methionine (100\%) & $28.80^{*}$ & $647.06^{*}$ & $984.80^{*}$ & $1.60^{*}$ & $3.33^{*}$ \\
\hline T3 - alternative methionine (110\%) & $30.34 *$ & $679.85^{*}$ & $1025.13^{*}$ & $1.59 *$ & $2.77 *$ \\
\hline T4 alternative methionine (120\%) & $28.38^{*}$ & $639.39 *$ & $936.62 *$ & $1.55^{*}$ & $2.77 *$ \\
\hline $\mathrm{CV}(\%)$ & 4.32 & 4.08 & 4.21 & 3.22 & 115.51 \\
\hline
\end{tabular}

CV $(\%)$ coefficient of variation

* Mean comparisons that reached significance $(p<0.05)$, as assessed by Tukey's tests

The seeking for alternative nutrition sources as a way to reduce production costs and increase metabolic performance has been a major area of recent research, which aims to optimize the poultry production (Araujo 2005). Amino acids have been used in diets to reduce ration protein content without decreasing animal performance. These diets also have the benefit of reducing nitrogen release in the environment and improving performance indexes and production (Sadiku and Jauncey 1995; Faria Filho et al. 2005). Limiting amino acids are those present in the diet at concentrations below those required for maximum protein synthesis (Kerr and Easter 1995). The methionine is considered the main limiting amino acid for the development and production of poultry, since it is a donor source of methyl radicals (Warnick and Anderson 1968), which are required for

Table 2 Effect of treatments on daily weight gain (DWG), live weight (LW), feed intake (FI), feed conversion (FC), and mortality (MO) in broilers of 1-42 days old

\begin{tabular}{|c|c|c|c|c|c|}
\hline Treatments & $\begin{array}{l}\text { DWG } \\
(\mathrm{g})\end{array}$ & LW (g) & $\mathrm{FI}(\mathrm{g})$ & $\mathrm{FC}$ & $\begin{array}{l}\text { MO } \\
(\%)\end{array}$ \\
\hline $\begin{array}{l}\mathrm{T} 1-99 \% \mathrm{DL}- \\
\text { methionine }\end{array}$ & $61.18^{*}$ & $2611.80^{*}$ & $4782.20 *$ & $1.83^{*}$ & $5.00 *$ \\
\hline $\begin{array}{l}\text { T2 - alternative } \\
\text { methionine } \\
(100 \%)\end{array}$ & $52.27 *$ & $2237.56^{*}$ & $4737.10^{*}$ & $2.10^{*}$ & $8.88^{*}$ \\
\hline $\begin{array}{l}\text { T3 - alternative } \\
\text { methionine } \\
(110 \%)\end{array}$ & $54.51^{*}$ & $2332.19 *$ & $4708.40 *$ & $2.03 *$ & $5.55^{*}$ \\
\hline $\begin{array}{l}\text { T4 alternative } \\
\text { methionine } \\
(120 \%)\end{array}$ & $51.88^{*}$ & $2222.21^{*}$ & $4717.90 *$ & $2.08^{*}$ & $10.00 *$ \\
\hline CV (\%) & 3.38 & 3.32 & 4.22 & 3.06 & 65.76 \\
\hline
\end{tabular}

CV $(\%)$ coefficient of variation

* Mean comparisons that reached significance $(p<0.05)$, as assessed by Tukey's tests the biosynthesis of essential body components for normal animal growth, such as choline, creatine, creatinine, polyamine, epinephrine, and melatonin. The inclusion of methionine in diets based on corn and soybean meal is fundamental to avoid losses in performance (Daenner and Bessel 2002). The imbalance in dietary methionine levels can be corrected by adding synthetic amino acids such as DL-methionine (in powder form) and methionine hydroxy analog-free acid (MHA-FA) (in liquid form) (Weerden and Schutte 1984).

Although the use of synthetic amino acids in poultry diets is common in conventional production, there are limitations to their use in productive systems of natural ideology, such as the organic production (Figueiredo and Soares 2012). Thus, the use of alternative methionine can be adopted as an alternative to traditional sources of synthetic methionine in this production system. The organic production system has grown steadily, due to an increasing demand for organic products (Alves et al. 2012).

The aim of this study was to evaluate the effects of using three levels of alternative methionine, replacing

Table 3 Effect of treatments on productive efficiency index (PEI) and flock uniformity (FU)

\begin{tabular}{lll}
\hline Treatments & PEI & FU (\%) \\
\hline T1—99 \% DL-methionine & $317.61^{*}$ & $60.33^{*}$ \\
T2 - alternative methionine $(100 \%)$ & $226.42^{*}$ & $35.66^{*}$ \\
T3 - alternative methionine (110\%) & $254.85^{*}$ & $44.83^{*}$ \\
T4 -alternative methionine (120\%) & $223.62^{*}$ & $44.33^{*}$ \\
CV (\%) & 7.57 & 30.09 \\
\hline
\end{tabular}

$C V(\%)$ coefficient of variation

*Mean comparisons that reached significance $(p<0.05)$, as assessed by Tukey tests 
Table 4 Ingredients and metabolizable energy and crude protein levels of the experimental diets during the initial and growth phases

\begin{tabular}{|c|c|c|c|c|c|c|c|c|}
\hline \multirow[t]{2}{*}{ Ingredients $(\%)$} & \multicolumn{4}{|c|}{ Initial (1-7 days of age) } & \multicolumn{4}{|c|}{ Growth (8-21 days of age) } \\
\hline & $\mathrm{T} 1$ & $\mathrm{~T} 2$ & $\mathrm{~T} 3$ & $\mathrm{~T} 4$ & $\mathrm{~T} 1$ & $\mathrm{~T} 2$ & $\mathrm{~T} 3$ & $\mathrm{~T} 4$ \\
\hline Corn & 46.315 & 46.315 & 46.295 & 46.234 & 59.025 & 59.025 & 59.013 & 59.000 \\
\hline Soybean protein Conc. (62\% of crude protein) & 12.000 & 12.000 & 12.000 & 12.000 & 12.000 & 12.000 & 12.000 & 12.000 \\
\hline Semi-integral soybean & 38.000 & 38.000 & 38.000 & 38.000 & 25.400 & 25.400 & 25.400 & 25.400 \\
\hline Dicalcium phosphate & 1.600 & 1.600 & 1.600 & 1.600 & 1.550 & 1.550 & 1.550 & 1.550 \\
\hline Limestone & 1.250 & 1.250 & 1.250 & 1.250 & 1.250 & 1.250 & 1.250 & 1.250 \\
\hline $\mathrm{NaCl}$ & 0.400 & 0.400 & 0.400 & 0.400 & 0.400 & 0.400 & 0.400 & 0.400 \\
\hline Mineral/vitamin premix ${ }^{a}$ & 0.120 & 0.120 & 0.120 & 0.120 & 0.120 & 0.120 & 0.120 & 0.120 \\
\hline Mineral/vitamin premix ${ }^{b}$ & 0.120 & 0.120 & 0.120 & 0.120 & 0.120 & 0.120 & 0.120 & 0.120 \\
\hline Choline & 0.015 & 0.015 & 0.015 & 0.015 & 0.015 & 0.015 & 0.015 & 0.015 \\
\hline DL-methionine $99 \%$ & 0.180 & - & - & - & 0.120 & - & - & - \\
\hline Alternative source of methionine & - & 0.180 & 0.200 & 0.216 & - & 0.120 & 0.132 & 0.145 \\
\hline Total & 100 & 100 & 100 & 100 & 100 & 100 & 100 & 100 \\
\hline Metabolizable energy $(\mathrm{MJ} / \mathrm{Kg})$ & 12.356 & 12.356 & 12.356 & 12.356 & 12.679 & 12.679 & 12.679 & 12.679 \\
\hline Crude protein & 25.700 & 25.700 & 25.700 & 25.700 & 21.900 & 21.900 & 21.900 & 21.900 \\
\hline
\end{tabular}

T1 reference diet formulated with synthetic methionine (DL-methionine $99 \%$ ), T2 diet replacing $100 \%$ of synthetic methionine with alternative methionine, T3 diet replacing $110 \%$ of synthetic methionine with alternative methionine, T4 diet replacing $120 \%$ of synthetic methionine with alternative methionine

${ }^{\mathrm{a}}$ Each kilogram of premix provides folic acid (min) $1000.00 \mathrm{mg}$, pantothenic acid (min) $13.00 \mathrm{~g}$, niacin (min) $32.00 \mathrm{~g}$, vitamin A (min) 10,000,000.00 UI, vitamin D3 (min) 2,450,000.00 mg, vitamin E (min) 18,000.00 UI, vitamin K3 (min) $3640.00 \mathrm{mg}$, vitamin B1 (min) $2400.00 \mathrm{mg}$, vitamin B2 (min) $6000.00 \mathrm{mg}$, vitamin B6 (min) $3200.00 \mathrm{mg}$, vitamin B12 (min) 15,600.00 mg, and selenium (min) $300.00 \mathrm{mg}$ ${ }^{\mathrm{b}}$ Each kilogram of premix provides iron ( $\left.\mathrm{min}\right) 60.00 \mathrm{~g}$, copper (min) $12.00 \mathrm{~g}$, manganese (min) $120.00 \mathrm{mg}$, zinc (min) $90.00 \mathrm{~g}$, and iodine (min) $1500.00 \mathrm{mg}$

DL-methionine $99 \%$, on the performance of broilers from 1 to 42 days old at the organic production system.

\section{Materials and methods}

The experimental period was conducted between the months of September and October of 2013. It took place at the experimental avian Korin Agropecuária Ltda Company (latitude -22.40214, longitude -47.68071) located in Ipeúna, State of São Paulo, Brazil. It used 720 1-day-old male chicks of Cobb-500 ${ }^{\circledR}$ commercial line, with an average initial weight of $42.00 \pm 0.34 \mathrm{~g}$. All chicks were vaccinated against Marek's, Avian Influenza, Gumboro, and Coccidiosis disease.

The animals were raised from 1 to 42 days of age. The Brazilian organic legislation does not require a minimum age to organic chicken slaughter (BRASIL 2011).

The conventional chicken barn was equipped with ventilation and nebulization systems. Lamps were used as heat sources to control the temperature in the first experimental week. The temperature and humidity were recorded daily throughout the experimental period.

The reference diet was based on corn and soybean meal (Rostagno et al. 2011). Neither anticoccidial nor animal products were added to the diets. The feeding program was divided into five phases: initial, 1 to 7 days; growth, 8 to 21 days; fattening I, 22 to 30 days; fattening II, 31 to 37 days, and final, 38 to 42 days, with water and food ad libitum.

Two sources of methionine were used, the DL-methionine $-99 \%$ and one alternative methionine source extracted from non-transgenic soybean. According to dos Santos et al. (2010), the most common process of soybean amino acid extraction is the enzymatic hydrolysis (Tables 1, 2, and 3).

The treatments were the following: T1-reference diet formulated with synthetic methionine (DL-methionine-99\%); T2 - diet replacing $100 \%$ of synthetic methionine with alternative methionine; T3 - diet replacing $110 \%$ of synthetic methionine with alternative methionine, and T4 - diet replacing $120 \%$ of synthetic 
Table 5 Ingredients and metabolizable energy and crude protein levels of the experimental diets during the fattening I and fattening II phases

\begin{tabular}{|c|c|c|c|c|c|c|c|c|}
\hline \multirow[t]{2}{*}{ Ingredients $(\%)$} & \multicolumn{4}{|c|}{ Fattening I (22-30 days of age) } & \multicolumn{4}{|c|}{ Fattening II (31-37 days of age) } \\
\hline & $\mathrm{T} 1$ & $\mathrm{~T} 2$ & $\mathrm{~T} 3$ & $\mathrm{~T} 4$ & $\mathrm{~T} 1$ & $\mathrm{~T} 2$ & $\mathrm{~T} 3$ & $\mathrm{~T} 4$ \\
\hline Corn & 61.975 & 61.975 & 61.964 & 61.953 & 66.345 & 66.345 & 66.336 & 66.327 \\
\hline Soybean protein conc. ( $62 \%$ of crude protein) & 12.000 & 12.000 & 12.000 & 12.000 & 12.000 & 12.000 & 12.000 & 12.000 \\
\hline Semi-integral soybean & 22.600 & 22.600 & 22.600 & 22.600 & 18.400 & 18.400 & 18.400 & 18.400 \\
\hline Dicalcium phosphate & 1.450 & 1.450 & 1.450 & 1.450 & 1.300 & 1.300 & 1.300 & 1.300 \\
\hline Limestone & 1.250 & 1.250 & 1.250 & 1.250 & 1.250 & 1.250 & 1.250 & 1.250 \\
\hline $\mathrm{NaCl}$ & 0.400 & 0.400 & 0.400 & 0.400 & 0.400 & 0.400 & 0.400 & 0.400 \\
\hline Mineral/vitamin premix $^{\mathrm{a}}$ & 0.100 & 0.100 & 0.100 & 0.100 & 0.100 & 0.100 & 0.100 & 0.100 \\
\hline Mineral/vitamin premix ${ }^{\mathrm{b}}$ & 0.100 & 0.100 & 0.100 & 0.100 & 0.100 & 0.100 & 0.100 & 0.100 \\
\hline Choline & 0.015 & 0.015 & 0.015 & 0.015 & 0.015 & 0.015 & 0.015 & 0.015 \\
\hline DL-methionine $99 \%$ & 0.110 & - & - & - & 0.090 & - & - & - \\
\hline Alternative source of methionine & - & 0.110 & 0.121 & 0.132 & - & 0.090 & 0.099 & 0.108 \\
\hline Total & 100 & 100 & 100 & 100 & 100 & 100 & 100 & 100 \\
\hline Metabolizable energy (MJ/Kg) & 12.765 & 12.765 & 12.765 & 12.765 & 12.888 & 12.888 & 12.888 & 12.888 \\
\hline Crude protein & 21.100 & 21.100 & 21.100 & 21.100 & 19.800 & 19.800 & 19.800 & 19.800 \\
\hline
\end{tabular}

$T 1$ reference diet formulated with synthetic methionine (DL-methionine $99 \%$ ), T2 diet replacing $100 \%$ of synthetic methionine with alternative methionine, T3 diet replacing $110 \%$ of synthetic methionine with alternative methionine, T4 diet replacing $120 \%$ of synthetic methionine with alternative methionine

${ }^{a}$ Each kilogram of premix provides folic acid ( $\left.\mathrm{min}\right) 1000.00 \mathrm{mg}$, pantothenic acid (min) $13.00 \mathrm{~g}$, niacin (min) $32.00 \mathrm{~g}$, vitamin A (min) 10,000,000.00 UI, vitamin D3 ( $\mathrm{min}) 2,450,000.00 \mathrm{mg}$, vitamin E (min) 18,000.00 UI, vitamin K3 (min) $3640.00 \mathrm{mg}$, vitamin B1 (min) $2400.00 \mathrm{mg}$, vitamin B2 (min) $6000.00 \mathrm{mg}$, vitamin B6 (min) $3200.00 \mathrm{mg}$, vitamin B12 (min) 15,600.00 mg, and selenium (min) $300.00 \mathrm{mg}$ ${ }^{\mathrm{b}}$ Each kilogram of premix provides iron ( $\left.\mathrm{min}\right) 60.00 \mathrm{~g}$, copper (min) $12.00 \mathrm{~g}$, manganese (min) $120.00 \mathrm{mg}$, zinc (min) $90.00 \mathrm{~g}$, and iodine (min) $1500.00 \mathrm{mg}$

methionine with alternative methionine. The diet formulations of each treatment in different phases are shown in the Tables 4, 5, and 6 .

The variables studied for the period from 1 to 21 days and from 1 to 42 days of age were live weight (LW), daily weight gain (DWG), feed intake (FI), feed conversion (FC), mortality (MO), flock uniformity (FU), and productive efficiency index (PEI).

The bird average weight was obtained by weighing all birds of each box. In each box, 30 broilers were housed. The daily weight gain was calculated by the difference between the final and initial weights of each period investigated. The feed intake was calculated by the difference between the total supplemented feed and the remaining feed in each period. Feed conversion rate was estimated by the ratio between total consumed feed and weight gain, then, corrected for mortality as proposed by Sakamura and Rostagno (2007). Mortality was daily recorded. The flock uniformity was expressed as the percent of individual weights which occurs within
$10 \%$ of the flock average. The PEI was calculated using the following equation: $\mathrm{PEI}=\left(\left(\mathrm{LW}^{*}(100-\mathrm{MO})\right) /\right.$ age*FC)*100.

The broilers were distributed using a completely randomized design including four treatments with six replicates of 30 chicks each, totaling 180 chicks per treatment.

Data were submitted to analysis of variance (ANOVA) with subsequent regression analysis using the GLM for higher sensitivity. Tukey's test was used to compare treatment means $(p<0.05)$.

\section{Results}

The average, maximum, and minimum temperature were 26,31 , and $20^{\circ} \mathrm{C}$, respectively, and average humidity was $69 \%$.

The performance of 1-21-day-old broilers (Table 1) indicated that animals fed with diets supplemented 
Table 6 Ingredients and metabolizable energy and crude protein levels of the experimental diets during the final phase

\begin{tabular}{|c|c|c|c|c|}
\hline \multirow[t]{2}{*}{ Ingredients $(\%)$} & \multicolumn{4}{|c|}{ Final (38-42 days of age) } \\
\hline & $\mathrm{T} 1$ & $\mathrm{~T} 2$ & $\mathrm{~T} 3$ & $\mathrm{~T} 4$ \\
\hline Corn & 67.505 & 67.505 & 67.497 & 67.489 \\
\hline Soybean protein conc. ( $62 \%$ of crude protein) & 12.000 & 12.000 & 12.000 & 12.000 \\
\hline Semi-integral soybean & 17.300 & 17.300 & 17.300 & 17.300 \\
\hline Dicalcium phosphate & 1.200 & 1.200 & 1.200 & 1.200 \\
\hline Limestone & 1.300 & 1.300 & 1.300 & 1.300 \\
\hline $\mathrm{NaCl}$ & 0.400 & 0.400 & 0.400 & 0.400 \\
\hline Mineral/vitamin $\operatorname{premix}^{\mathrm{a}}$ & 0.100 & 0.100 & 0.100 & 0.100 \\
\hline Mineral/vitamin premix ${ }^{\mathrm{b}}$ & 0.100 & 0.100 & 0.100 & 0.100 \\
\hline Choline & 0.015 & 0.015 & 0.015 & 0.015 \\
\hline DL-methionine $99 \%$ & 0.080 & - & - & - \\
\hline Alternative source of methionine & - & 0.080 & 0.088 & 0.096 \\
\hline Total & 100 & 100 & 100 & 100 \\
\hline Metabolizable energy (MJ/Kg) & 12.923 & 12.923 & 12.923 & 12.923 \\
\hline Crude protein & 19.500 & 19.500 & 19.500 & 19.500 \\
\hline
\end{tabular}

T1 reference diet formulated with synthetic methionine (DL-methionine $99 \%$ ), T2 diet replacing $100 \%$ of synthetic methionine with alternative methionine, T3 diet replacing $110 \%$ of synthetic methionine with alternative methionine $T 4$ diet replacing $120 \%$ of synthetic methionine with alternative methionine

${ }^{\mathrm{a}}$ Each kilogram of premix provides folic acid (min) $1000.00 \mathrm{mg}$, pantothenic acid (min) $13.00 \mathrm{~g}$, niacin (min) $32.00 \mathrm{~g}$, vitamin A (min) 10,000,000.00 UI, vitamin D3 (min) 2,450,000.00 mg, vitamin E (min) 18,000.00 UI, vitamin K3 (min) $3640.00 \mathrm{mg}$, vitamin B1 (min) $2400.00 \mathrm{mg}$, vitamin B2 (min) $6000.00 \mathrm{mg}$, vitamin B6 (min) $3200.00 \mathrm{mg}$, vitamin B12 (min) 15,600.00 mg, and selenium (min) $300.00 \mathrm{mg}$

${ }^{\mathrm{b}}$ Each kilogram of premix provides iron ( $\left.\mathrm{min}\right) 60.00 \mathrm{~g}$, copper (min) $12.00 \mathrm{~g}$, manganese (min) $120.00 \mathrm{mg}$, zinc (min) $90.00 \mathrm{~g}$, and iodine (min) $1500.00 \mathrm{mg}$

with $99 \%$ synthetic DL-methionine had significantly higher $(p<0.05)$ daily weight gain (DWG), live weight (LW, ) and feed intake (FI) than chicks raised with alternative methionine diet (Table 1). Chicks bred with diet containing $120 \%$ alternative methionine had the lowest feed intake (Table 1). However, no differences in feed conversion were detected between treatments (diets) $(p>0.05)$, indicating similar metabolic efficiency between both sources tested (i.e., $99 \%$ synthetic DL-methionine and alternative methionine) in this period. There were no significant differences $(p>0.05)$ between treatments in terms of mortality.

In the period of 1-42 days old (Table 2), chicks supplemented with $99 \%$ DL-methionine showed higher $(p<0.05)$ DWG, LW, and better feed conversion (FC). There were no significant changes $(p>0.05)$ in FI parameters and mortality (MO) during the same period.

Animals supplemented with DL-methionine $99 \%$ showed higher PEI in the end of the experimental period
(Table 3). Broilers supplemented with diets containing 110 and $120 \%$ of the alternative methionine showed the same flock uniformity results compared to broilers fed with the $100 \%$ synthetic methionine. The use of alternative methionine in $100 \%$ proportion resulted in lower flock uniformity (Table 3).

\section{Discussion}

The reasons of the low broiler performance fed with alternative methionine source are still not totally enlightened. However, there are some hypotheses. The most probable one is due to the differences in amino acid uptake between both sources. According to Partridge et al. (1985) and Barbi et al. (2004), amino acid absorption may change according to the source and its molecular availability in the food used, while the absorption of synthetic amino acids is more efficient. This hypothesis of lower availability is enhanced due to the nonalteration of birds' feed intake of alternative source 
treatments (Table 2). Therefore, there was no lower intake of protein and energy by birds of T2, T3, and T4. It discards the possibility of palatability problems due to the use of alternative source.

The amino acid methionine may play a direct or indirect role in numerous fundamental metabolic processes, such as protein, skin and feather synthesis, and optimization of the immune response and stress response (Rodrigueiro 2010). Then, the lower flock uniformity of the treatment which replaced $100 \%$ of the DL-methionine $99 \%$ with alternative methionine is probably due to limitations imposed to these processes. The limitations were minimized in the $\mathrm{T} 3$ and $\mathrm{T} 4$, which have higher alternative methionine replacement (Table 3). However, the productive efficiency indexes of the alternative methionine treatments in different replacement proportions (100, 110, and $120 \%)$ were statistically inferior comparing to the DL-methionine $99 \%$ treatment. Considering the percentage of methionine was equivalent in both sources, according to the information provided by manufacturers, the results pointed out that the replacement of synthetic methionine with alternative source negatively affected the production efficiency.

The use of synthetic amino acids in organic production, over many years, has been a subject of frequent discussions. Since June of 2014, the Normative Instruction $\mathrm{N}^{\circ} 17$ (Brasil 2014) started to amend the Normative Instruction $\mathrm{N}^{\circ} 46$ (BRASIL 2011), allowing the use of such substances. Their use, however, is based on the prevention of nutritional deficiencies and diseases and consequently improving animal welfare. In this moment, it is important to emphasize that this permission is based on the lack of alternative sources with similar efficiency as the synthetic ones.

In conclusion, the use of alternative methionine extracted from soybeans to replace DL-methionine $99 \%$ resulted in significantly lower broiler performance. Thus, more researches in alternative amino acids sources are necessary to accomplish better results.

\section{References}

Alves ACO, Santos ALS, Azevedo RMMC (2012) Agricultura orgânica no Brasil: sua trajetória para a certificação compulsória. Rev Bras Agroecologia 7(2):19-27

Araujo DM (2005) Avaliação do farelo de trigo e enzimas exógenas na alimentação de frangas e poedeiras. Dissertação, Universidade Federal da Paraíba
Barbi JHT, Dibner J, Peak S (2004) Mais que uma fonte de metionina. Rev AveWord 11:25-27

Belusso D, Hespanhol ANA (2010) Evolução da avicultura industrial brasileira e seus efeitos territoriais. Rev Percurso 2(1):25-51

BRASIL (2011) Ministério da Agricultura. Pecuária e Abastecimento-MAPA. Instrução Normativa n. 46. Estabelece o Regulamento Técnico para os Sistemas Orgânicos de Produção Animal e Vegetal, bem como as listas de substâncias permitidas para uso nos Sistemas Orgânicos de Produção Animal e Vegetal. Diário Oficial. Brasília. 07 out. 2011. Seção $1.32 \mathrm{p}$

BRASIL (2014) Ministério da Agricultura. Pecuária e Abastecimento-MAPA. Instrução Normativa n. 17. http:// www.agricultura.gov.br/comunicacao/noticias/2014/06/ regras-para-sistemas-organicos-de-producao-sao-ajustadas. Accessed 25 Sept 2014.

Daenner E, Bessel W (2002) Effectiveness of liquid DLmethionine hydroxy analogue-free acid (DL-MHA-AL) compared to DL-methionine on performance of laying hens. Arch Geflügelkunde 66(5):97-101

dos Santos RE, Groff AM, Assad NF (2010) Teores de proteína solúvel e aminoácidos livres em farinha de soja hidrolisada com enzimas. Encontro de Produção Científica e Tecnológica - EPCT, V. Campo Mourão

Espíndola CJA (2009) Cadeia produtiva de frango de corte na América do Sul: considerações preliminares. Encontro de Geógrafos da América Latina. http://paraiso.ifto.edu.br/ docente/admin/upload/docs_upload/material_52297e0a38. pdf. Accessed 13 Oct 2013

Faria Filho DE, Rosa PS, Vieira BS, Macari M, Furlan RL (2005) Protein levels and environmental temperature effects on carcass characteristics, performance and nitrogen excretion of broiler chickens from 7 to 21 days of age. Braz J Poul Sci 7(4):247-253

Figueiredo EAP, Soares JPG (2012) Sistemas orgânicos de produção animal: dimensões técnicas e econômicas. In: Reunião Anual da Sociedade Brasileira de Zootecnia, 49. Brasília, pp 1-31

Kerr BJ, Easter RA (1995) Effect of feeding reduced protein. Amino acid-supplemented diets on nitrogen and energy balance in grower pigs. J Anim Sci 73(10):3000-3008

Partridge IG, Low AG, Keal HD (1985) A note on the effect of feeding frequency on nitrogen use in growing boars given diets with varying levels of free lysine. Anim Prod 40:375-377

Rodrigueiro R (2010) O que esperar da betaína como fonte poupadora da DL-metionina suplementar. Technical Services Evonik Degussa Brazil. Evonik Industries. http:// www.avisite.com.br/cet/img/20101105_evonik.pdf. Accessed 30 Oct 2013.

Rostagno HS, Albino LFT, Donzele JL, Gomes PC, Oliveira RF, Lopes DC, Ferreira AS, Barreto SLT, Euclides RF (2011) Tabelas brasileiras para aves e suínos: composição de alimentos e exigências nutricionais. UFVDZO, Viçosa

Sadiku SOE, Jauncey K (1995) Digestibility, apparent amino acid availability and waste generation potential of soybean flour: poultry meat blend based diets for tilapia. Oreochromis niloticus (L), fingerling. Aquac Res 26:651-657

Sakamura NK, Rostagno HS (2007) Métodos de pesquisa em nutrição de monogástricos. FUNEP, Jaboticabal 
Warnick RE, Anderson JO (1968) Limiting essential amino acids in soybean meal for growing chickens and the effects of heat upon availability of the essential amino acids. Poult Sci 47(1):281-287
Weerden EJ, Schutte JB (1984) Comparison of DL-methionine, DL-methionine-Na, DL-methionine hydroxy analogue-Ca, and DL-methionine hydroxy analogue free acid with layers. Poult Sci 63(9):1793-1799 